\title{
皮虐多發性骨腫の一例
}

\section{A case of multipal Osteoma cutis}

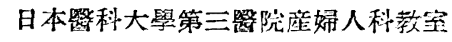

研觉生田
(泣任 三谷 茂教授)

邊良

Tanabe Saburo

\section{緒言}

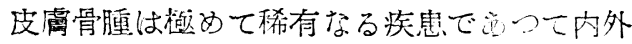

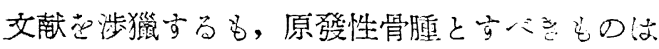
10 症例きこえない, 且つ多莎性定型的の症例 は 1908 年 Heidingsfeld の報告以外江结見営 らない。本邦汇於て子淡中, 薄坦, 正畑, 古賀 渡遥(正), 渡遥(昭), 樋口光本兩氏, 大森氏等 の例が离るが二二除いては不死化表皮朠の化 管例ですつて何れ已孤立したもので点。最近

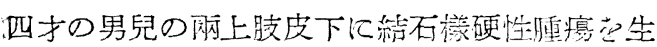
して左时閶節强直, 右时關節部の不全强直异 たしたので此の腫演の除去芑希望して籍者の自 宅に來院し广此の例几觀血的整形手衔怘施し， 除去した腄瘤の一部の組織檢查行さ、稀一有な

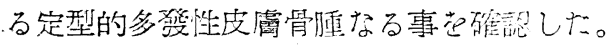

\section{症例}

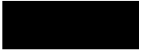
男于 昭和 21 年5月 15 日丝 初診：昭和 25 年 10 月 26 日

主訴：网側时譬節運動障倡

本症の既往並儿經過：出生㭙汇网肘關節部 て小指頭大の赤い斑點が台り，澌次この玟點が 援大硬化し上腕並びに前腕更に手掌にまで波及

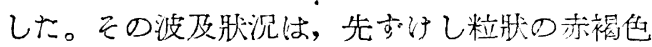
の玟點が，次々に弧立性に生じ，2 万至 3 ケ月 で漸次硬く皮下にふれるようにる，半米粒大 上b次第几硬化し，或るものは癒合して鳵卵大 の大きさに達したものもある。 2,3 近醫の診

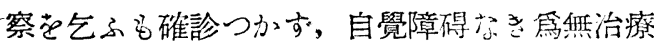
に經過した。生後 3 年目より左时關節の渾動障 碍が起り, 最近では直角位に屈曲せるま 殆ん ど運動不能となつた。更に昨年 6 月頃より右时

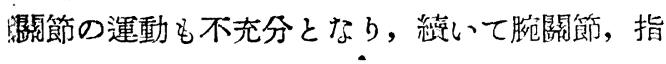

箅節沉去で浬動障害が波及するので來院した。

家族歷：两親健在，近親結婚でもない。ま

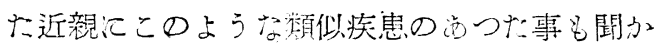
奴。同泡 3 人, 姉 2 人, 弟 1 人何就健, 母, 本人法にワッセルマン氏反應陰性，皖任に磨瘆

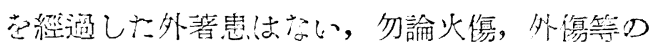
既往行标い。

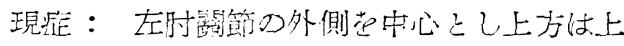

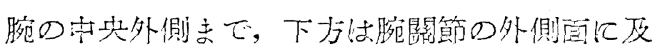

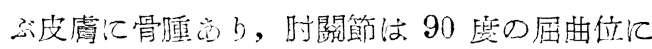

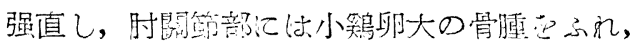

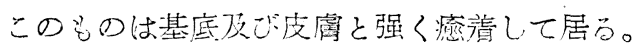
上腕贡び前腕外側部の骨朠は小志るものは半米

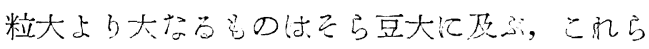

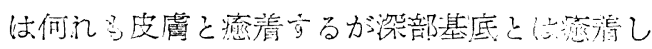

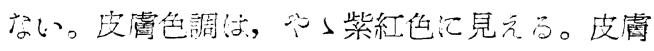

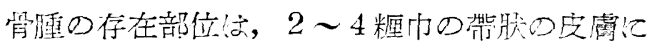

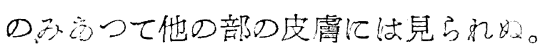

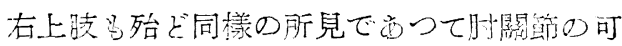

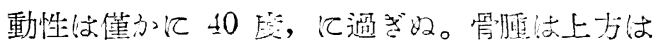

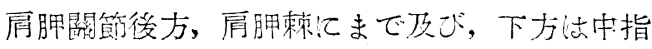
及び第 4 指の第1基節に去で及んでるる。又右

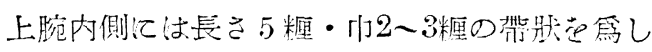

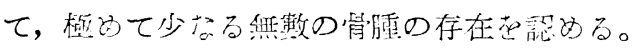
(别絉分乍圆參照)

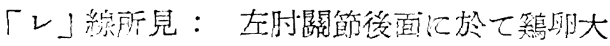

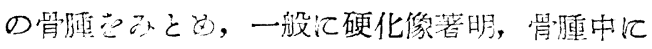

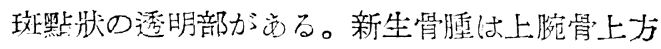

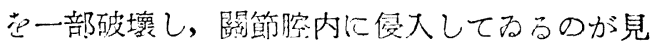

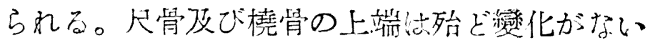

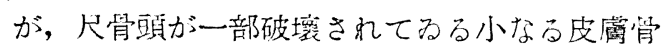
陣は「レ」線像上にはあらはれぬ。右肘關節当 
$-158-(158)$

殆ど同樣な所見であるが，尺骨及び橈骨の上端 にも骨腫に上る骨破壞を認めることができる。

10 月 29 日 左上䁌の手術苍施行した。

手術所見：左上肢，左上腕伸側中央部から 前腕の上， $1 /:$ 境界部江亘つて，皮膚病變部兩側 飞皮膚切開苍加へ，皮膚及び皮下の硬結組織を 除去した。三の際时關節伸側は甚だ硬固にして 皮膚は淔接骨に癒着したものの如く可動性がな い。他の部分の皮鬳及び皮下組織は大部分骨樣 若しくは軟骨樣硬臣で，筋組織仁も一部波及し てるることが認められるが、骨との癒着は認め られぬ。上腕骨下端は骨の性狀苍失ひ骨質, 海 綿質の區別なく，一樣に粗弉㳂して骨の破壤さ れてるるのさ認めることができる。前腕骨は周 圍の軟部, 筋隆組織と癒合して硬固なる組織と 化し, 固有の性狀巳失ひ，末稍部及び中樞部に 近づくに徒ひ，筋膜樣組織より，正常の符組織 に兴行してるる。關節内は增殖した軟骨樣組織 で老滿し，關節面は全く認められない。此の増 殖したる關節内組織さ除去, 相互の癒合苍剥離 病變組織苍悉く清掃して關節邑可動性にした。 しかる尚後筋肉綎合, 筋膜縫合, 皮膚縫合, で手 術を終了した。術後上腕上端より, 前腕下端に 及ぶギプス䌃帶，「リンゲル」500cc「ペニシ リン」150 萬單位, 「トロンボーゲン」3 筒注 射, 創面は一期痖合した。

右上凌手術 11 月 12 日

左上肢汇比して病變比皎的輕臨であつたから 时關節伸側の略及中央に於て約 5 糎の縱皮切開 を加へ，之上り外側の皮膚病變部は表而より剝 離除去し，内側の病變部は主として皮下に深く

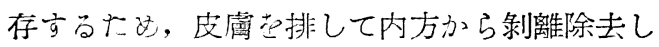

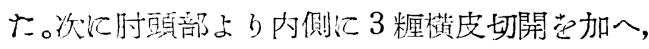
更桜皮切開声下方に 3 糎延長して, 前腕の病 變部芭切除した。三頭腕筋梳萎縮して, 筋瀻維

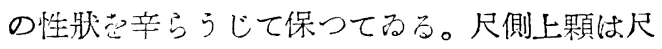
骨と癋着し，尺骨神經は周葍の化骨した軟部組 轼に埋没せられてるる。この神經さできるだけ 遊離し骨性癒着も剥䧺して, 關節運動艺可能な らしめ，三頭腕筋の延長維合荧行つて創苍閉鎻 した。
11 月 26 日 第3 回目の手術を施行した。郎 ち兩上肢皮膚殘部の皮膚骨腫苍除去した。術後 の經過良好で, 左时關節可動性は約 30 度とな つた。また右时關節可動性は約 90 度となつた。

\section{組織學的所見}

此の部の皮膚上皮は比較的薄く，不規則であ る。表面は極めて不平坦で, 所によつては皮内 深部に突入するの像が見られる。また所により ては表皮組織の廣沉なる壞死の像が見られる。

兴組織绀皮膚汃ら皮下に及んで不規則且つ散 在性江存在してるる。其の形は種々で圆形, 隋 圆形, 梁狀, 網目狀苍星するものがある。此等 の骨組織は周睹の皮膚或は皮下脂肪組織内に島. 嶼狀法出現し，周圍飞骨の移行組織を認めない ものと, 所に依りては周圍に緻密な結合織や， 硝子樣化しだ組織㐫り漸次骨組織に移行して居 る部分とが認められる。何双島與狀のものでも 骨新生組織の譛められるものと, 然らざるもの とが西る。及骨組織の周圍浩骨細胞の發生を 見るものと念いものと㐫り, 文破骨細胞が破骨 の機轉圭示して居るものもある。一般汇皮膚の 部分の骨組織は小さく，皮下組識汇及ぶもの或 は皮下深部鬲るものはや」大きな梁狀, 或ひ は網目狀苍示してるる。網目狀を示すもの〉網 目の間は脂肪組識で，筒髓樣造棈苍示するのは 殆んど認められない，しかし所によりては骨髓 巨大細胞は認めら礼ないが, 毛細血管の增生, 僅かながら造血樣所見が認められる。一部には 骨細胞が無棈造で，壞死の樣な所見苍示す部分

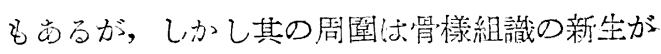

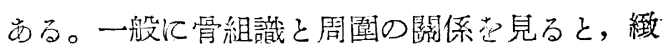
密な結合識上り骨組識の新生に及ふ化生の像 が，認められれ㤂い所見が多いが, 所によりては, 肥厚した極めて緻密な細胞配列艺見る骨膜同樣 な組識芭見る师已吕る。以上の如き組識標本及 び，臨床所見からして，本患者の骨の成因は徽 毒, 外傷, 炎症江組識の崩壞に依万骨形成等が 考へられない點加らして, 先天的の肧芽の異常 によるものと思はれる。只本例で最も興味市る ことは，正常なる發育をとげた毛諼の像を認め 得ないことで, 而る極めて小なる骨組識, 或は 
骨原基と思恬れるものは，皮脂腺に隣接して 1 或は. 2 個存在することで, 其の初期の像がまた 毛根の像に酷似する所苍以てすれば，その發生 が毛笼と密接なる關係のあることは疑ふ餘地が ない。

\section{考按}

皮膚管腫の成因に就ては種々の報告がある。 Meyer (1951) 络，一老婦人の慢治漬瘍に，本 病の發生したこと報告してるる。Wikkens (1858) 岋上皮腫の化筲苞記載してるる。所謂 原發生骨腫と見做すべきものは，Colemann

(18４）の6才の女兒の足蹠に，1粗厚さの骨 片を剔出した報告の学るのが最初の樣で市る。 其の他 Taylor and Mac, Kenna (1908) は

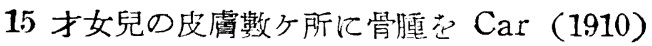
は 2 才兒の耳下に, Becker は一婦人の頭皮に，

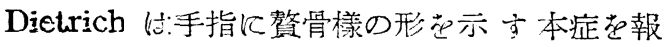
告してるる。Salzer，Strossberg 岋頭皮や足背 に原因不明の皮膚骨腫芭報告してるる。Musger

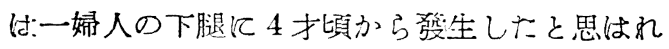
る例艺報告してるる。本邦沉於て淡中（大14）， 西畑（昭10）氏等の例付先ずこれ等の報告に一 致する原發性の骨腫で离る。Maeherbe, Eve, Hutchinson Nicolson 等恃上皮腫の化督例を 報告してるるが, 本邦に於ても薄場, 渡邊(正), 渡䢙(昭), 大森, 古賀, 樋口光本, 兩氏の例忏 石灰化表皮の化骨例である。

開腹術後の般痕江骨腫を形成したと云子報告 は, Rokitansky（1852）飞甫まb Didier Natol, Pierson and Nervig の報告がある。

Lloyd-William 仕 30 年前の火傷性洀痕加ら 本症を發生したこと垠告しだ。

其他の皮膚疾患から筂全した報告に KreuzProg (1902) の天疮瘡患者の四肢に, Pollitzer (1910) の顔面琗皮症に, Trimble (1920) の 䫏面籸斑性狼瘡から本症を發生したことを報告 してるる。また Hopkins (1928) は 44 才の老 女の痤瘡が，本症を惹起した例を報告してるる が，殆んど同樣の例を Morris Leider (1950) が長期間重症痤瘡の結果として, 皮膚骨腫を發 生したことを報告してるる。
先天性の还種晎常から本症芯發生した報告は Heidingsfeld (1908) の例で，有毛性母斑上り

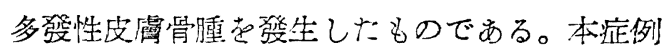
も生後既に时關節部位儿赤い母玟があつて，こ れ上り潮次皮膚骨腫芭發生しきたれるるので文 つて, 其の發生初期の狀態付, 同氏の例と全く 相一致吕るもので西る。而して其の後の狀態苍

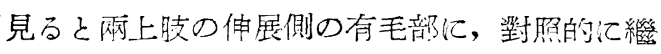

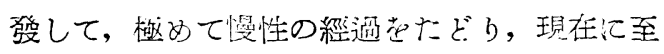
つたものであつて, 其の多數に發生してるる部 位儿纳，最早毛疑苍認めない，即古前述した如 くに毛根の肧種異常より笪生したことが明らか であつて，極ぬて興味ある例である。

管形成の機喠て就て Sehrt は6つの場合范 擧げてるる。1. 石灰化皮膚裂腫の化学吩ら起

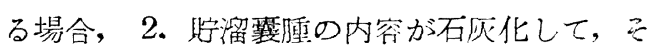

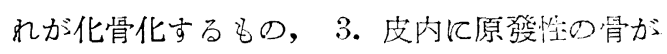

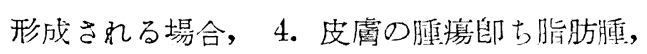
淋巴腫, 癌腫などから骨が新生される場合,

5. 慢性炎症で学る梅瑇敄, 慢性皮膚炎の經啲 中沿の形成さ机る場合，6. 高年者つ下肢伸 側皮下に存在する脂肪組識から骨が形方される 場合。

また Hopkins は.皮盧の胃形成せ3つの型に 分類してるる。1. 先行した障害の垫めること のできない場所经形成苍認める。2. 上皮腫 内の骨形成, 郎古石灰沈着と加, 化生現集,

3. 炎症及び退化現秘の市る組識内の骨形成, 即古皮膚炎，潰㾤；痕洀などである。

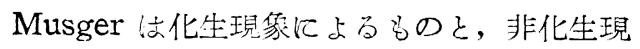
象に上るものと 2 つ分類して, 前者は病的組 織, 腫痛, 萿腄, 畸形, 洀痕, 又心肉芽組織上

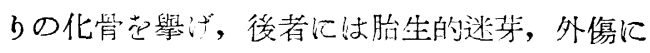
上る骨慔片の蹧位, 遺傅的素筫, 肖系統の腫境 の轉位による化骨苍擧げてるる。

要するに胎生的迷芽络誰れでも唱へる所では 岕るが，未だ筲つて毛根の胚種貲常から骨形成 吅唱へたものはな。

本症の腄影は單發が多發かでる。还種異常 による Heidingsfeld の例は多發で 50 個以上 と記載されてるるが，佾多く存在してるたこと 
$-160-(160)$

さ想像することが出來る。本例では盤數で, 恐 らく毛根の數だけ發生するであらうことを想像 することができる。

大いさは雷粒大から拇指頭大に及んでるる。 皮雐と痖着してるるが，底とは移動性がある。 右の如く硬いが疼痛は它まりない。本例では兩 时關節部の腄演は，鷄卵大に及んで上腕骨，尺 骨撓骨破壞して, 關節内に侵入乙て, 强直を きたしたものではる。骨の形は球形，板狀，種

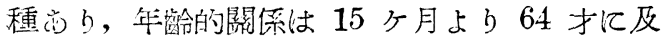
んで汸る。性汇は關係はない㨾で西る。

診斷は上記の症狀により簡單にて, 特に「レ」 線像に上り碓認される。但し石灰化せる上皮腫, 粉瘤等と鑑別診㫁され和ばなら奴ことは勿論で 㐫る。治療法は障碍のあるをきは剔出手術芭行 ふ外はない。特汇肧種異常によるものは處置な
し。

豫後は生命に對しては一般に可良である。 本症の遠隔成績は手術後 4 ケ月時に於ては可 動性は著しく增し, 皮膚の膨隆も除去されした め, 家人も喜び居たるも約 1 年にして再び以前 と同じく上腕の强直ききたした。佾今後腫痬の 再發如何に關して，他日發表の㙨岕ることを附 記する。

結論

稀有なる皮膚多發性骨腫に，觀血的手術を加 へ, 病理熛本茄觀察したるに毛根の还種異常に よるものなること確認し得た。

稿导終るに當り御懇篤なる御指導と御校閲の 勞を賜りたる三谷教授に深甚なる謝意を捧ぐ。 本報告は大要は昭和 26 年 6 月 19 日第 12 回日本醫科大學第三醫院研究會で報告した。

\section{本症例皮膚骨缠分布模型四}

左上肢外側

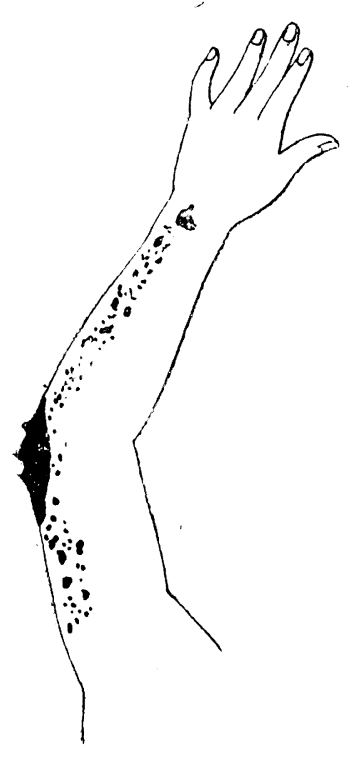

右上肢外側

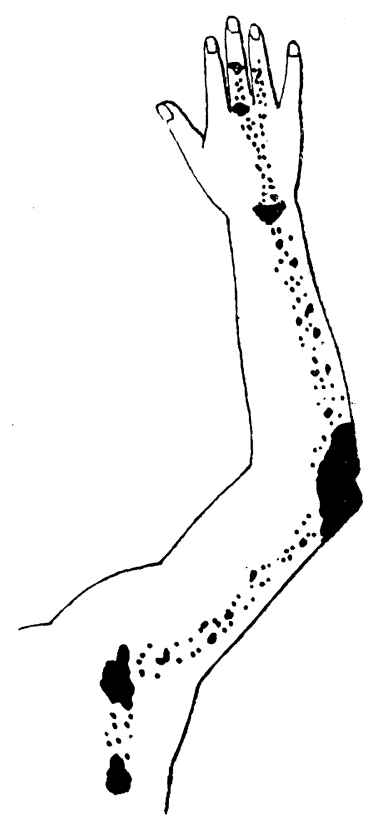

右上肢内側

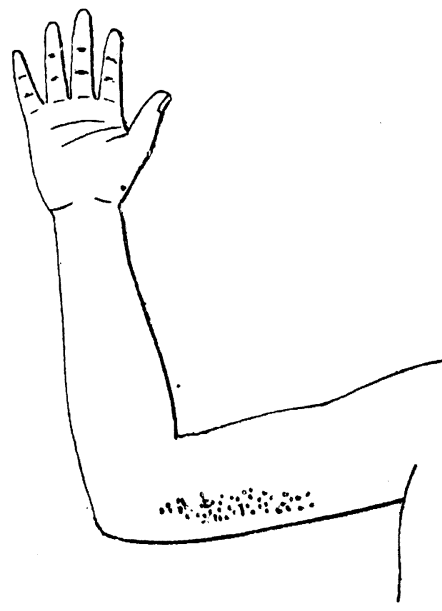




\section{附圖 [2]}

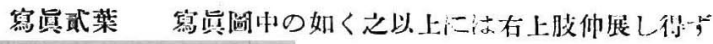
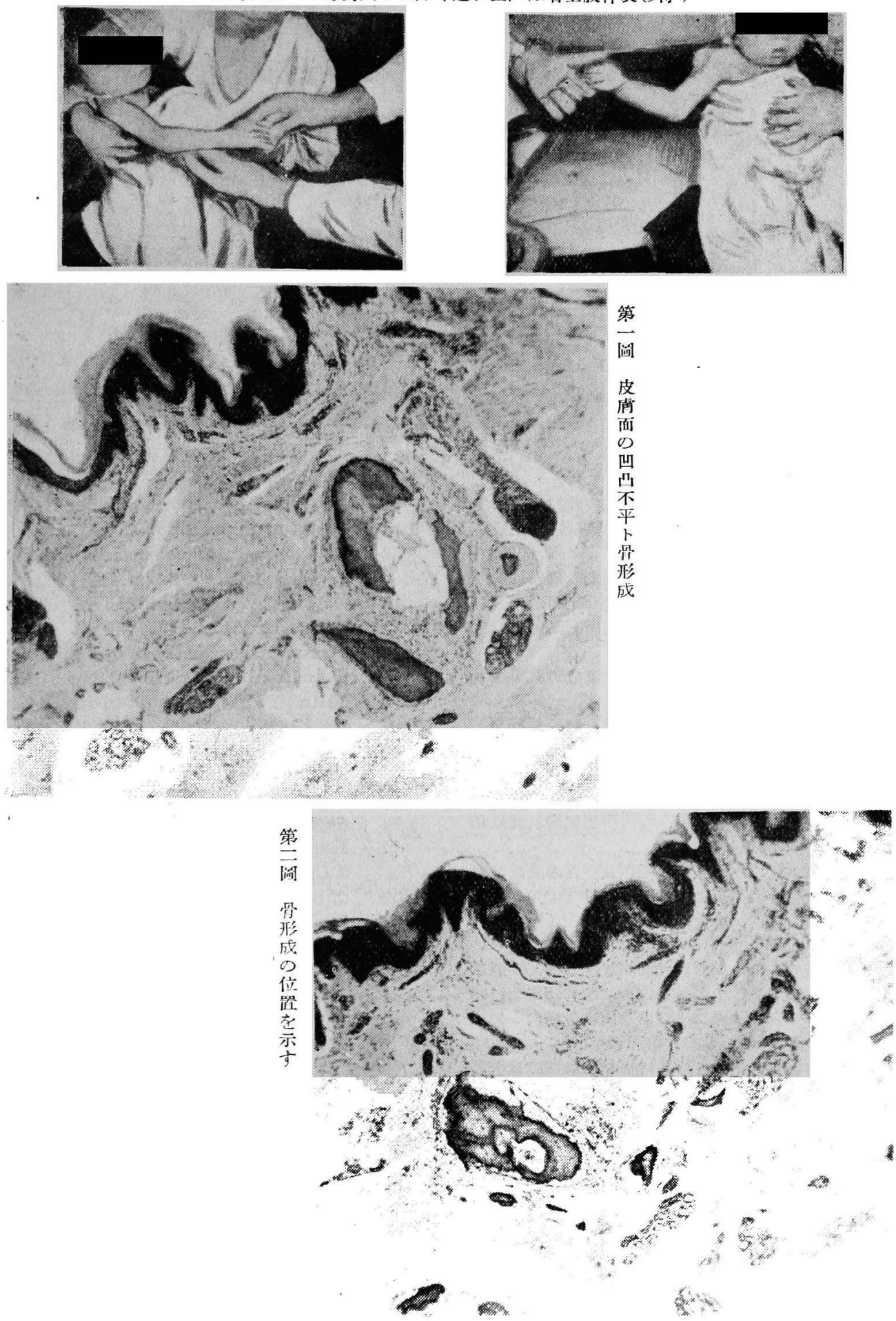


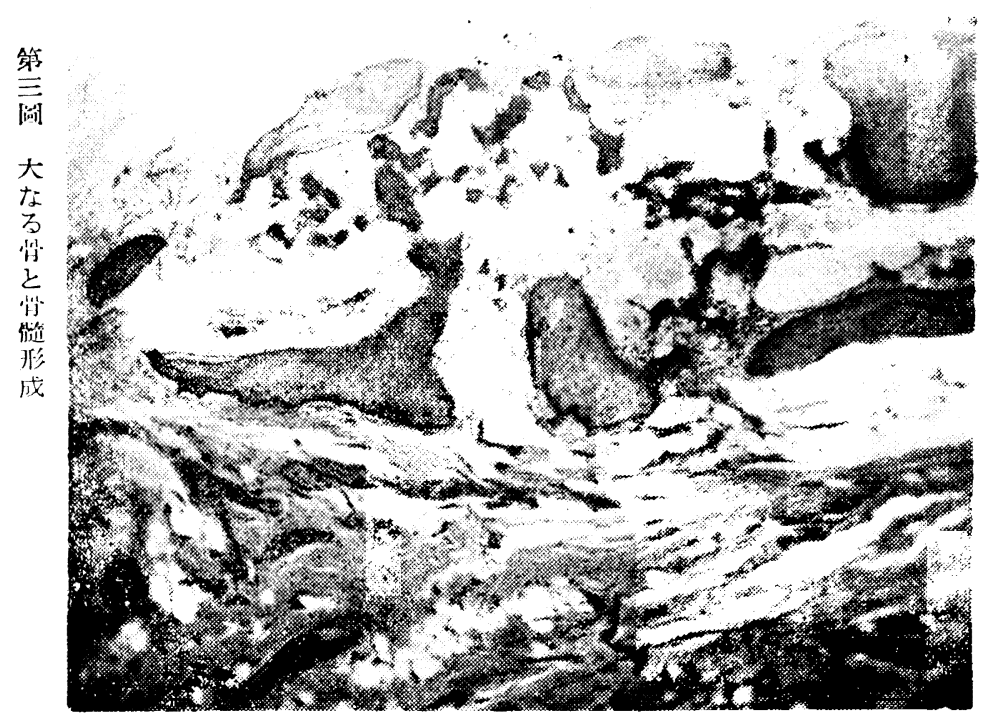

文献

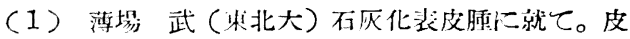

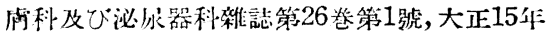
1月

（2）薄埸 武，不灰化表皮肺の迎加。皮局科及び 泌原器科雜誌第 28 巻第 3 號炤利 3 壬決 3 月

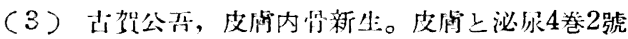

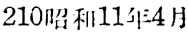

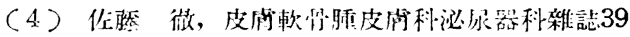

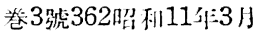

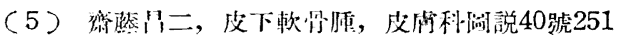
昭利11外 12 月

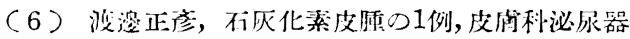
科新誌 43 巻 4 號 502 炤利 3 件 4 月

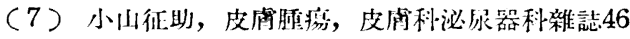
巻4號利籼14作10月

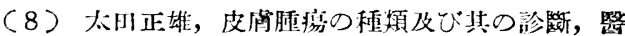

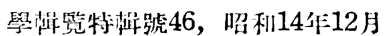

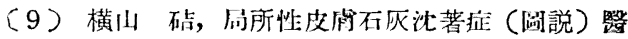
界相叝314號35，炤利16年2月

（10）大森周三郎，局所性皮届石灰沈著症（皮成絬

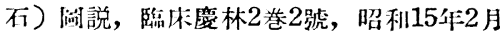

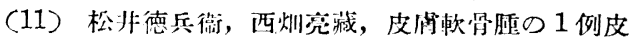
府利紀要 38 巻1號39, 炤利16年7月

(12) 山川一直，川村一既，皮阿絬石站びに皮消䋨 不拉の「レ」線分析的所兄，日本祭學及び健

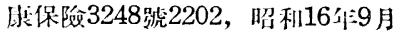

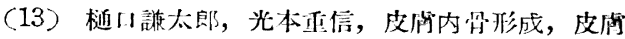

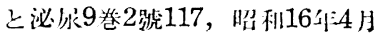

外國交献

(1) Carl, Exnchondroosteoma der Haut A.f Derm, u. Syph. 1910.

(2) Heidingsfeld, Asteoma cutis A.f. Derm. u. Syph. 1906.

(3) Kolaczek, Enchondrom der Halses. Branis B. 1910.

(4) Strassberg, Über ein ossifizieren des Chondrom, A.f. Derm, u. Syph. 1913.

(5) Zalin, Über congenitate Knorpelreste am Hals: Virchow. A. CXV.

(6) Morris Leider, Osteoma cutis as a result of severe Acne Vulgaris of long. duration. Archiv. Derm. and Syph. Sept. 1950 P. 403.

(7) Leider M. Osteoma cutis, Report of a Case. Arch. Derm. and Syph. $58: 168$ (Aug. 1948)

(8) Costello M. Metaplasia of Bone, Report of a Case, Arch. Derm. and Syph. $56: 536$ (Oct. 1947)

(9) Hopkins J.G. Multiple Miliary Osteomas of the Skin, Report of a Case, Arch. Derm. and Syph. 18:706 (Nov. 1928). 